\title{
A FEW NEW PSAMMOCHARIDA.
}

\section{By Nathan Banks.}

East Falls Church, Va.

\section{Psammochares transversalis n. sp.}

९. Black; face silvery each side of the antennæ, wings black. Clypeus truncate, margined; antennæ long, slender, third joint very long, as long as width of the face at antennæ; a very distinct line from antennæ to anterior ocellus, latter a little more than its diameter from the smaller laterals, these as close to the eyes as to each other; vertex, from in front, barely rounded; face rather narrow, narrowed above; eyes large. Pronotum depressed behind, and almost angulate; metanotum moderately long, with a median line on the basal part, and the apical part plainly transversely wrinkled; abdomen broad at base, dull, last segment rather brownish, fringed; legs slender, tarsi I with long cilia, more than twice as long as the width of a joint, hind legs not very heavily spinose, hind tibia with the longer spur nearly one-half as long as the metatarsus, last joint of hind tarsus with spines beneath, claws toothed. Wings of moderate length; marginal cell long, acute, second submarginal cell about twice as long as broad, first recurrent vein near the tip; third submarginal shorter, nearly one half narrowed above, second recurrent vein arising much beyond the middle of the outer cell, and running nearly straight to the middle of the third submarginal; basal veins interstitial in the fore-wings, widely dislocate in the hind-wings.

Length $13 \mathrm{~mm}$.

From Palmerlee, Arizona (Biederman). Readily known by wrinkled metanotum.

\section{Psammochares castella n. sp.}

$\sigma^{7}$. Small, narrow, black, not silvery, except on the lower part of the face, second abdominal segment mostly dull red above. Head and thorax very sparsely hairy; clypeus truncate in front, not margined; face broad, especially above; antennæ heavy; a faint line from antennæ to anterior ocellus, latter scarcely more than its diameter from the laterals, and these as close to eyes as to each other; vertex from in front very distinctly rounded; pronotum angulate behind; metanotum short, suddenly depressed behind; abdomen broad at base, dull, apical segment with a marginal fringe; legs slender, only slightly spinose, hind tibia with only three spines above, more on sides, longer spur of hind tibia more than one-half as long as the metatarsus, last tarsal joint without spines below. Wings long and narrow, black, not darker at tips; marginal cells large, submarginals small, second larger than third, latter triangular; first recurrent near tip of second submarginal, 
second recurrent arises a trifle beyond middle of outer cell and runs into third submarginal joint just beyond middle.

Length $6 \mathrm{~mm}$.

\section{From Fedor, Lee County, Texas, May.}

\section{Psammochares tenuicornis n. sp.}

$\sigma^{7}$. Black, very sparsely hairy. Clypeus truncate; antennæ very slender, the third joint plainly longer than the fourth; a distinct line from antennæ to anterior ocellus, latter fully its diameter from the equal laterals, and these nearer to each other than to the eyes; vertex slightly rounded; face rather broad; pronotum strongly arcuate behind, almost argulate; metanotum with distinct median line, not hairy; abdomen rather narrow at base, no tufts of hair below near tip; legs slender, tibiæ with many short, small spines, longer spur of hind tibia barely onehalf the length of the metatarsus; spines under last joint of hind tarsus; claws toothed. Wings slender, marginal cell long, nearly rounded at tip; second submarginal cell one and a half times longer than broad, receiving the first recurrent beyond middle, third submarginal about as long as second, but little narrowed above, second recurrent arising beyond middle of outer cell and curving outward to the third submarginal; basal veins dislocated in fore wings, interstitial in hind wings.

Length $11 \mathrm{~mm}$.

From Southern Pines, North Carolina, May.

The forms allied to Ps. philadelphicus and Ps. athiops may be tabulated as follows:

Pronotum angulate behind

Clypeus emarginate; hind wings with the basal veins disjointed philadelphicus.

Clypeus truncate; basal veins interstitial in hind wings.........illinoiensis.

Pronotum arcuate behind

Clypeus deeply emarginate, head very hairy ................ aethiops.

Clypeus barely emarginate, less hairy $\ldots \ldots \ldots \ldots \ldots \ldots \ldots \ldots \ldots$ ilione.

\section{Psammochares ilione n. sp.}

Black; hairy, but vertex not as hairy as in Ps. athiops; clypeus barely emarginate in front, third joint of antennæ not near as long as the vertex width; the line from antennæ to the anterior ocellus obliterated in the middle; the anterior ocellus its diameter from the smaller laterals, these as close to each other as to eyes; vertex faintly rounded; face rather broad (broader than in Ps. philadelphicus); pronotum hairy, arcuate; metanotum short, the line indistinct; abdomen broad at base, rather dull black, apical segment with long black hairs; anterior tarsi with long cilia; hind tibiæ with the longer spur one-half of the metatarsus, spines below on last joint of hind tarsi. Wings rather long, marginal cell long, acute, second submarginal trapezoidal, first recurrent vein near tip; third submarginal almost 
triangular, second recurrent arises a little beyond middle of outer cell and curves slightly outward to the middle of third submarginal; basal veins nearly interstitial in the hind wings.

Length 13-15 mm.

From Falls Church, Va.; Southern Pines, N. C.; and Sea Cliff, N. Y. This may be what has been called athiops in the East, but very distinct from the athiops of Colorado, which, however, I have also from Ithaca, N. Y.

Psammochares (Allocyphonyx) harpalyce n. sp.

Color and general appearance as in Ps. maura; but the male is distinct therefrom by prominent silvery hairs on the posterior slope of the metanotum, and the extreme tip of abdomen is pale; the antennæ are the same, and venation similar to $P s$. maura, but the basal veins dislocated in the hind-wings (interstitial in Ps. maura); last joint of hind tarsi without spines beneath.

Length 12-15 mm.

\section{Southern Pines, North Carolina.}

Psammochares (Allocyphonyx) hesione n. sp..

$\sigma^{7}$. Black; clypeus truncate in front; antennæ short not very heavy; head rather broad, hairy; anterior ocellus its diameter from the smaller laterals, latter as near to eyes as to each other; vertex, from in front, barely rounded; pronotum arcuate behind; metanotum short, hairy, suddenly bent down behind; abdomen broad at base, depressed; legs heavily spinose, several spines on hind femora, even half way to the base, longer spur of hind tibia nearly three-fourths as long as metatarsus; no spines under last joint of hind tarsi; claws cleft. Wings much as in Ps. maura; the second submarginal cell very short, third nearly triangular, the second recurrent arising beyond the middle of the outer cell and running somewhat sinuously to the middle of the third submarginal cell; basal veins interstitial.

Length $15 \mathrm{~mm}$.

From Douglas and Hamilton Counties, Kansas (Snow). Related to $P s$. maura, but the legs are more heavily spinose, and the antennæ do not have such a strongly serrate appearance.

\section{Gryptocheilus idoneus n. sp.}

․ Deep black, wings uniformly deep black or a little paler (not darker) at tips; clypeus margined, slightly, evenly emarginate, antennæ slender, but not near as long as head and thorax, third joint one and a half the length of first joint, scarcely one-half so thick; vertex slightly rounded; anterior ocellus fully its diameter from the nearly equal laterals, these very much nearer to each other than 
to the eyes; pronotum slightly angulate behind; metanotum with a distinct median groove, not transversely striate; abdomen dull black, hairy near tip, not much depressed; legs slender, spiny, the hind tibia more slender than in $C$. fortis and with short but stout spines above, longer spur about two-fifths of the metatarsus, last tarsal joint with distinct spines beneath (not in C. fortis). Wings not very long, marginal cell rounded at tip (like $C$. terminatus); second submarginal plainly longer than broad, receiving the first recurrent at middle; third submarginal barely longer than broad, narrowed above; second recurrent arising much beyond middle of anal cell, curving outward to the middle of the third submarginal cell; basal veins dislocated in fore wings, nearly interstitial in the hind wings.

Length $12 \mathrm{~mm}$.

From Southern Pines, N. C., July 14.

Pseudagenia antennalis $\mathrm{n}$. sp.

ㅇ. Iridescent blue, much like Ps. ccerulescens, but differs from that species by the antennæ (except black basal joints) being yellowish-brown, and the anterior legs, except dorsal part of femora at base, are pale; the middle and hind tarsi are brown, and the tegulæ are also brown. In structure also similar to Ps. ccerulescens, but the third joint of the antennæ is shorter than in that species, being only a little longer than the fourth joint; and the second discoidal cell of fore-wings is proportionately shorter and broader than in Ps. crerulescens. Of the same size.

From Fedor, Lee County, Texas, May 29, Birkmann Coll., through Prof. C. F. Baker.

Pseudagenia virginica n. sp.

$\sigma^{7}$. Black, with slight silvery pubescence, coxæ silvery, the spurs white, no white at tip of abdomen. Clypeus truncate, antennæ not very heavy, no line from antennæ to ocelli; anterior ocellus fully twice its diameter from the laterals, the latter a little closer to each other than to the eyes, vertex from in front slightly rounded, face rather long and narrow; hind margin of pronotum impressed, arcuate; metanotum short, rounded, transversely impressed near tip; abdomen slender, hardly petiolate, apical lower margin of first segment produced below; legs slender, longer spur of hind tibia nearly one-half as long as the metatarsus. Wings nearly uniformly smoky; the marginal cell rather long, acute; second submarginal onehalf narrowed above, receiving the first recurrent vein before middle; third submarginal larger, one-half narrowed above, the second recurrent arises from beyond middle of apical cell, and runs obliquely to beyond middle of third submarginal cell.

Length $6 \mathrm{~mm}$.

From Falls Church, Va., July 4, 1910. 

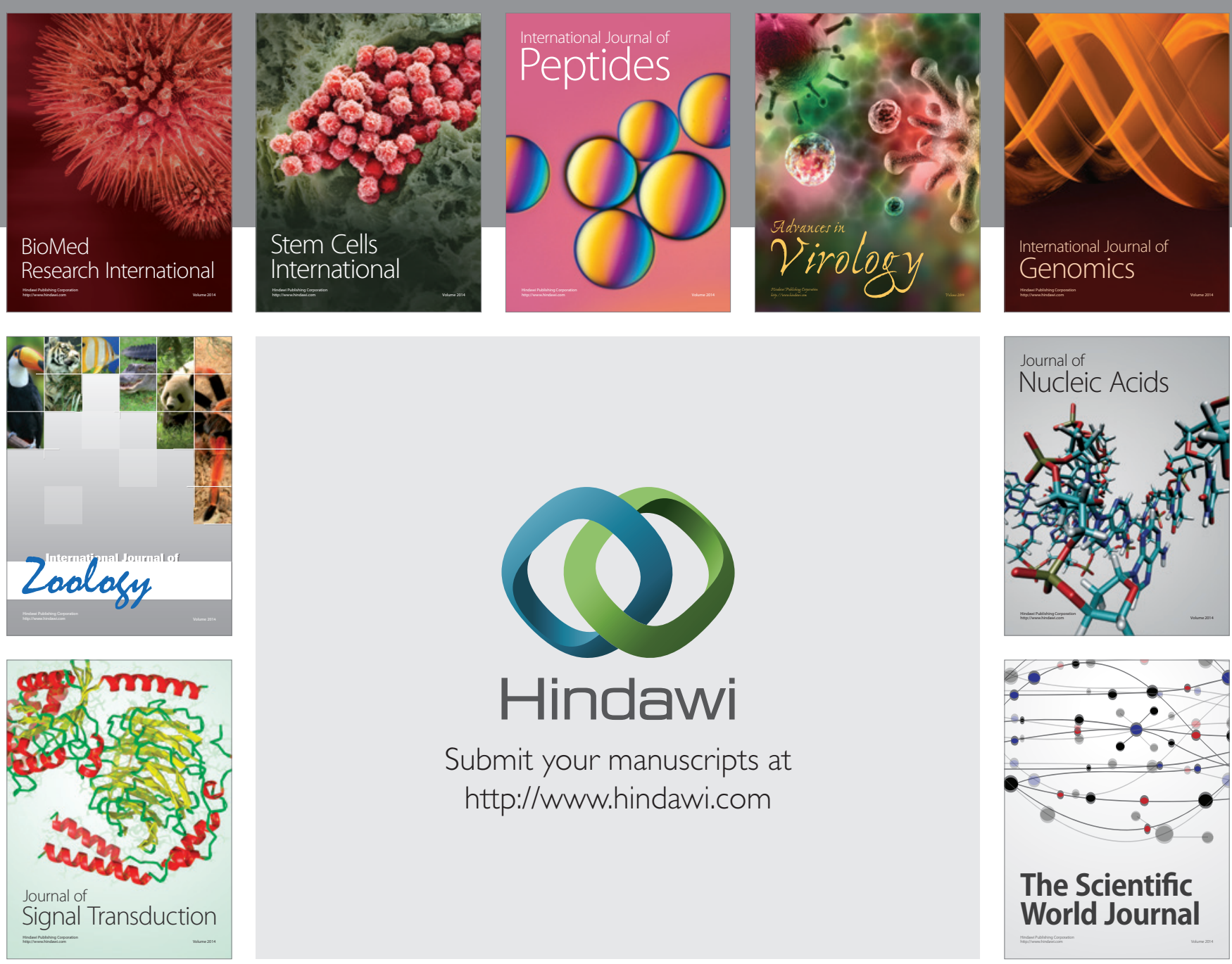

Submit your manuscripts at

http://www.hindawi.com
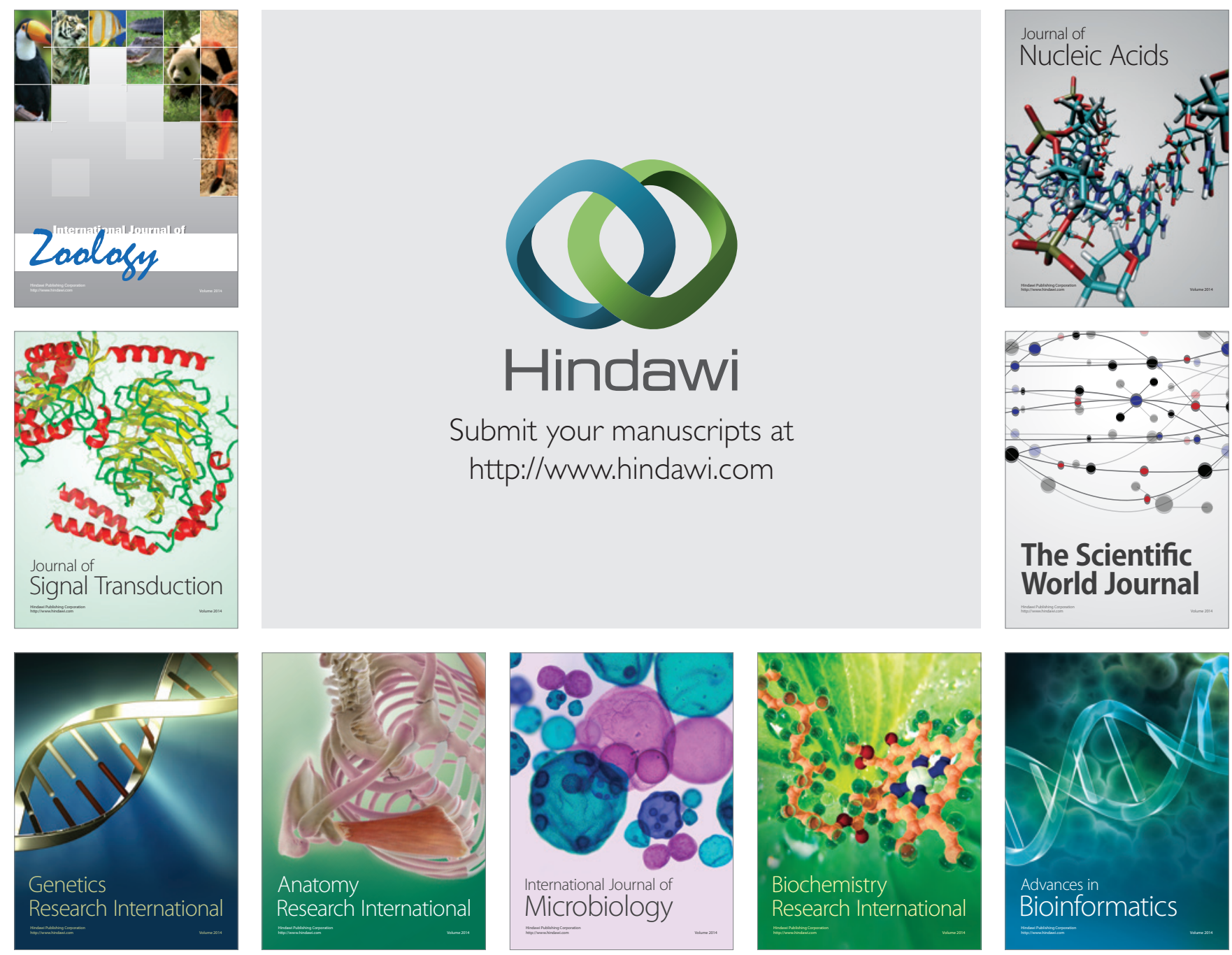

The Scientific World Journal
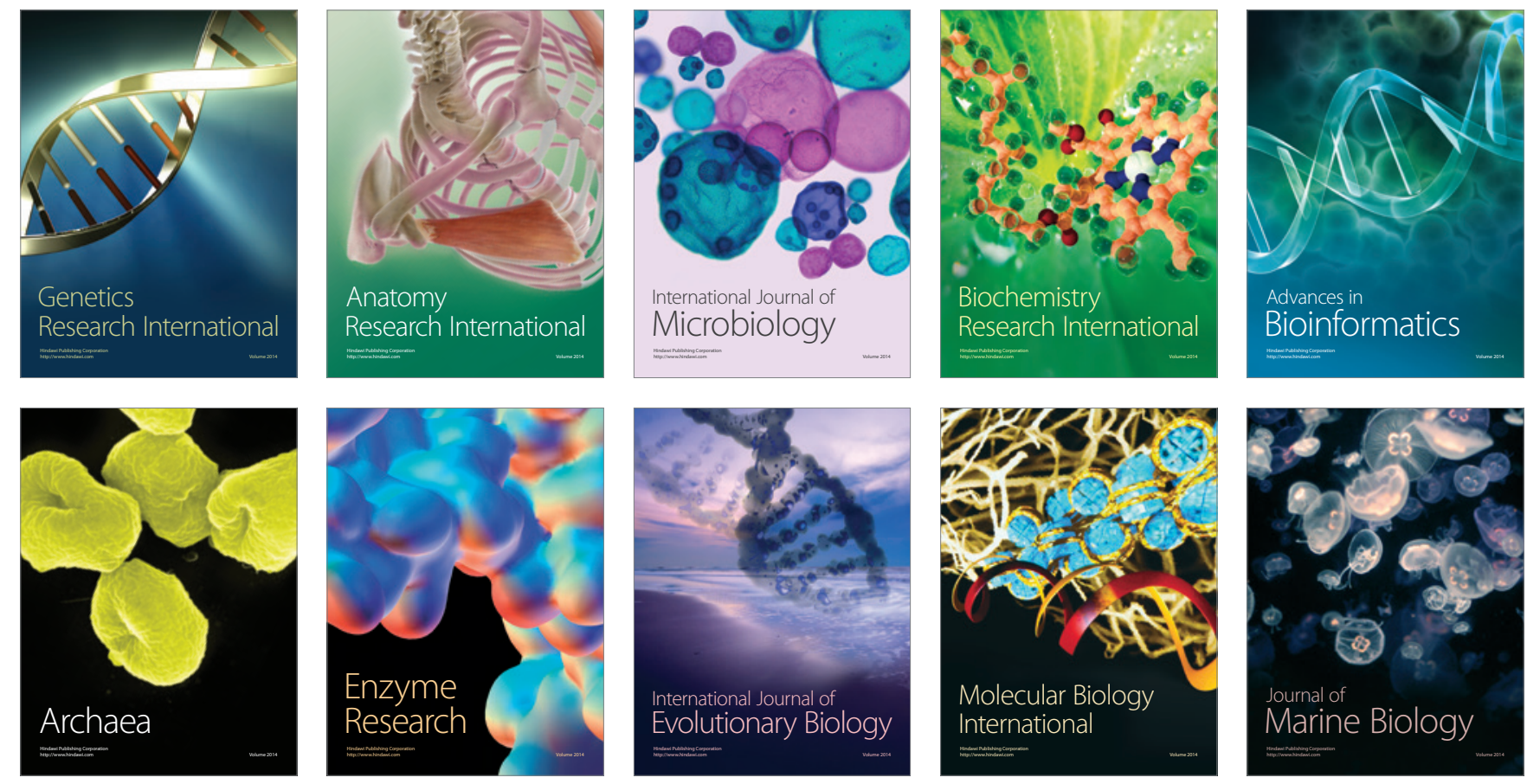